Historic, Archive Document

Do not assume content reflects current scientific knowledge, policies, or practices. 


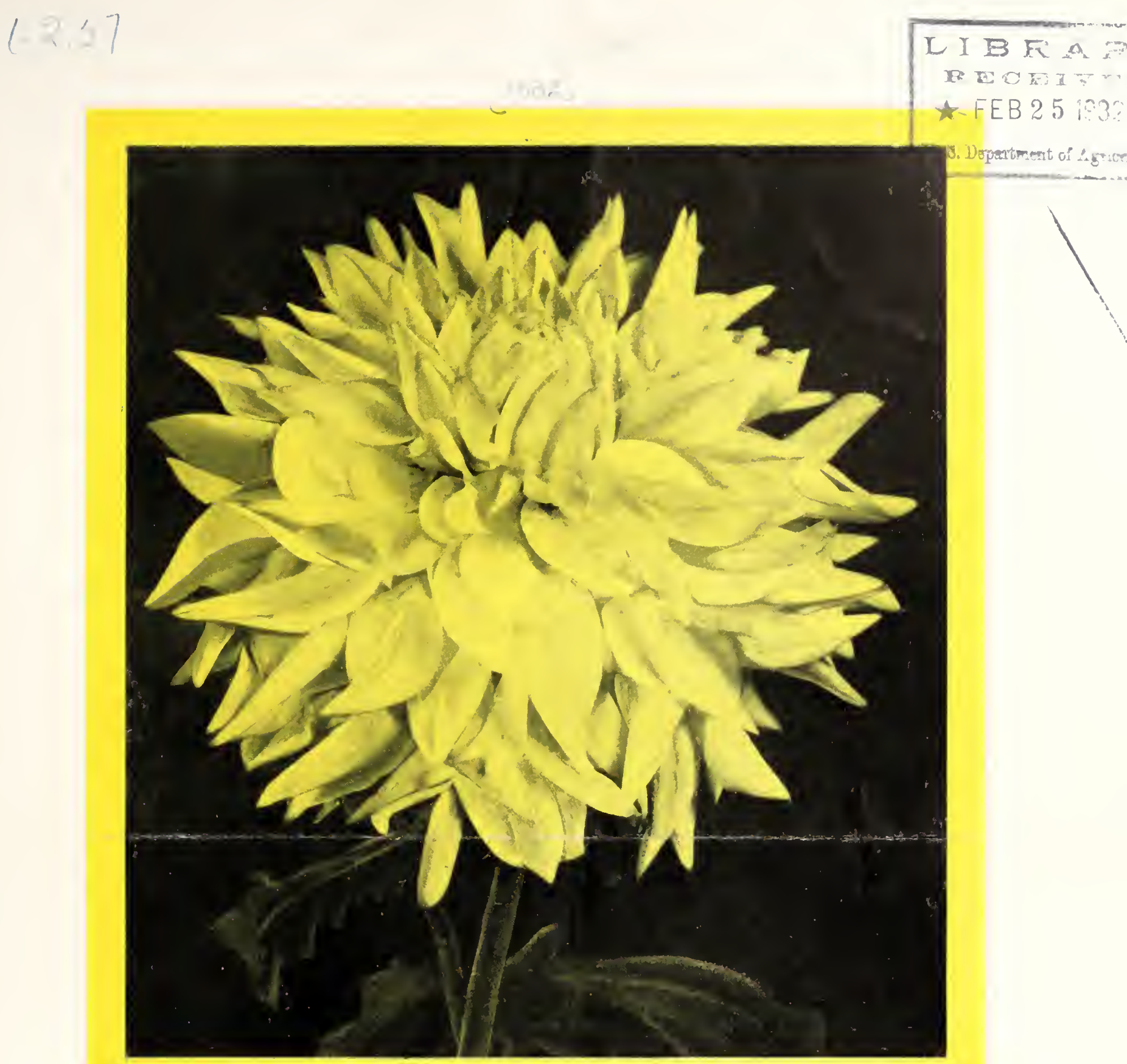

\section{Dahlia American Legion}

Named in honor of the wounded Veterans of the World War. American Legion is the largest and most perfect of all Dahlias. The gorgeous, bright, yellow semi-cactus blossoms are held on perfect long stems over a tall, robust bush. American Legion measuring $13 \frac{1}{2}$ inches in diameter and 9 inches in depth, was shown at the Atlantic City Flower and Garden Pageant, wimning the Pageant Gold Medal and $\$ 100$ for the best undisseminated seedling (open to all); Honorary President's Cold Medal and \$.50 for the best new Dahlia of New Jersey origin; the American Home Achievement Medal for the Dahlia or Dahlia exhibit which contributed most to the progress of the Dahlial in a class of 710 entries. The highest award ever won by any Dahlia. At Canden won the Gold Medal for the largest and most perfect Dahlia.

\section{TUBERS \$15.00 - PLANTS \$7.50}

DELITERED W'IIEN REQUESTED

SELECTEI) DAHLIA SEED: - 100 SEED, $\$ 5.00 ; 50$ SEED, $\$ 2.50$

\section{American Dahlia Farms}


$m$ 